\title{
Seed Production and Dispersal of Sulfur Cinquefoil in Northeast Oregon
}

\author{
Kathleen A. Dwire, ${ }^{1}$ Catherine G. Parks, ${ }^{2}$ Michael L. McInnis, ${ }^{3}$ \\ and Bridgett J. Naylor ${ }^{4}$ \\ Authors are ${ }^{1}$ Research Riparian Ecologist, USDA Forest Service, Rocky Mountain Research Station, \\ 240 W Prospect Rd, Fort Collins, CO 80526-2098; \\ ${ }^{2}$ Research Plant Pathologist, USDA Forest Service, Pacific Northwest Research Station, La Grande, OR 97850; \\ ${ }^{3}$ Associate Professor, Department of Rangeland Ecology and Management, Oregon State Univesity, Corvallis, OR 97331; and \\ ${ }^{4}$ GIS Specialist, USDA Forest Service, Pacific Northwest Research Station, La Grande, OR 97850.
}

\begin{abstract}
Sulfur cinquefoil (family Rosaceae) is an invasive, herbaceous perennial, native to Eurasia. It has wide ecological amplitude and has become established throughout North America in numerous habitat types. Sulfur cinquefoil reproduces only by seed (achenes); however, little is known about its regenerative strategy or reproductive biology. To improve understanding of the mechanisms of expansion for sulfur cinquefoil, we quantified seed production and measured seed dispersal at sites infested with sulfur cinquefoil in different habitats in northeast Oregon. Seed dispersal was measured by using sticky traps $(30 \times$ $100 \mathrm{~cm}$, replaced every 2 weeks) radiating in 4 cardinal directions from individual source plants. Estimated seed production for 2 years (2001 and 2002) was nearly 4 times higher than previously reported $(\approx 6000$ seeds per plant; range $\approx 2620$ 15150 seeds per plant). For most sites, seed production was similar in both years. However, site, year, and their interaction (site $\times$ year) had significant influence on flower and stem production. Seeds were dispersed from July through midOctober 2001, although almost $40 \%$ of the seeds were captured between mid-July and mid-August. Dispersal followed a classic decay function; approximately $83 \%$ of the seeds were captured within $60 \mathrm{~cm}$ of the source plants. Once sulfur cinquefoil reaches a site, it appears to spread and persist by releasing numerous seeds near the parent plants, thereby forming increasingly dense stands.
\end{abstract}

\section{Resumen}

El "Sulfur cinquefoil" (familia de las Rosaceae) es una especies herbácea perenne, invasora, originaria de Eurasia. Tiene un rango ecológico amplio y se ha establecido a lo largo de Norteamérica en numerosos tipos de hábitat. El "Sulfur cinquefoil" se reproduce solo por semilla (aquenios); sin embargo, poco se sabe acerca de su estrategia regenerativa o biología reproductiva. Para mejorar el conocimiento de los mecanismos de expansión del "Sulfur cinquefoil" cuantificamos la producción de semilla y medimos la dispersión de semilla en sitios infestados con esta especie en diferentes hábitats del noreste de Oregon. La dispersión de semilla fue medida usando trampas con pegamento $(30 \times 100 \mathrm{~cm}$, remplazadas cada dos semanas $)$ alrededor de los cuatro puntos cardinales a partir de plantas individuales que eran la fuente de semilla. La producción estimada de semillas para dos años (2001 y 2002) fue casi cuatro veces mayor que la reportada previamente $(\approx 6000$ semillas por planta; rango $\approx 2620-15150$ semillas por planta). En la mayoría de los sitios la producción de semilla fue similar en ambos años. Pero, el sitio, el año y su interacción (sitio $\times$ año) tuvieron una influencia significativa en la producción de flores y tallos. Las semillas fueron dispersadas de Julio a mediados de Octubre, aunque casi el $40 \%$ de las semillas fueron capturadas entre mediados de Julio y mediados de Agosto. La dispersión siguió la clásica función de decaimiento; aproximadamente $83 \%$ de las semillas fueron capturadas dentro de $60 \mathrm{~cm}$ de las plantas fuente. Una vez que el "Sulfur cinquefoil" alcanza un sitio, parece que se disemina y persiste liberando numerosas semillas cerca de las plantas madre, formando así poblaciones densas en constante expansión.

Key Words: Potentilla recta L., invasive species, regenerative strategy

\section{INTRODUCTION}

This research was supported by the USDA Forest Service (National Fire Plan).

Mention of a proprietary product does not constitute a guarantee or warranty of the product by USDA or the authors and does not imply its approval to the exclusion of the other products that also may be suitable.

At the time research was conducted, the senior author was postdoctoral researcher, Department of Forest Science, Oregon State University, Corvallis, OR 97333.

Correspondence: Kathleen A. Dwire, USDA Forest Service, Rocky Mountain Research Station, 240 W Prospect Rd, Fort Collins, C0 80526-2098. Email: kadwire@fs.fed.us

Manuscript received 16 February 2005; manuscript accepted 13 October 2005.
Sulfur cinquefoil (Potentilla recta L., Hitchcock and Cronquist 1973), a native of Eurasia, was introduced to North America prior to 1900 (Britton and Brown 1897). In the past 2 decades, this species has been recognized as having broad ecological amplitude in drier climates of northwestern North America, where it forms dense stands and is considered a threat to native plant communities (Rice 1991, 1999; Powell 1996). Sulfur cinquefoil has probably gone unnoticed in many parts of its range because this nonnative species is similar in appearance to native co-occurring congeners, particularly northwest cinque- 


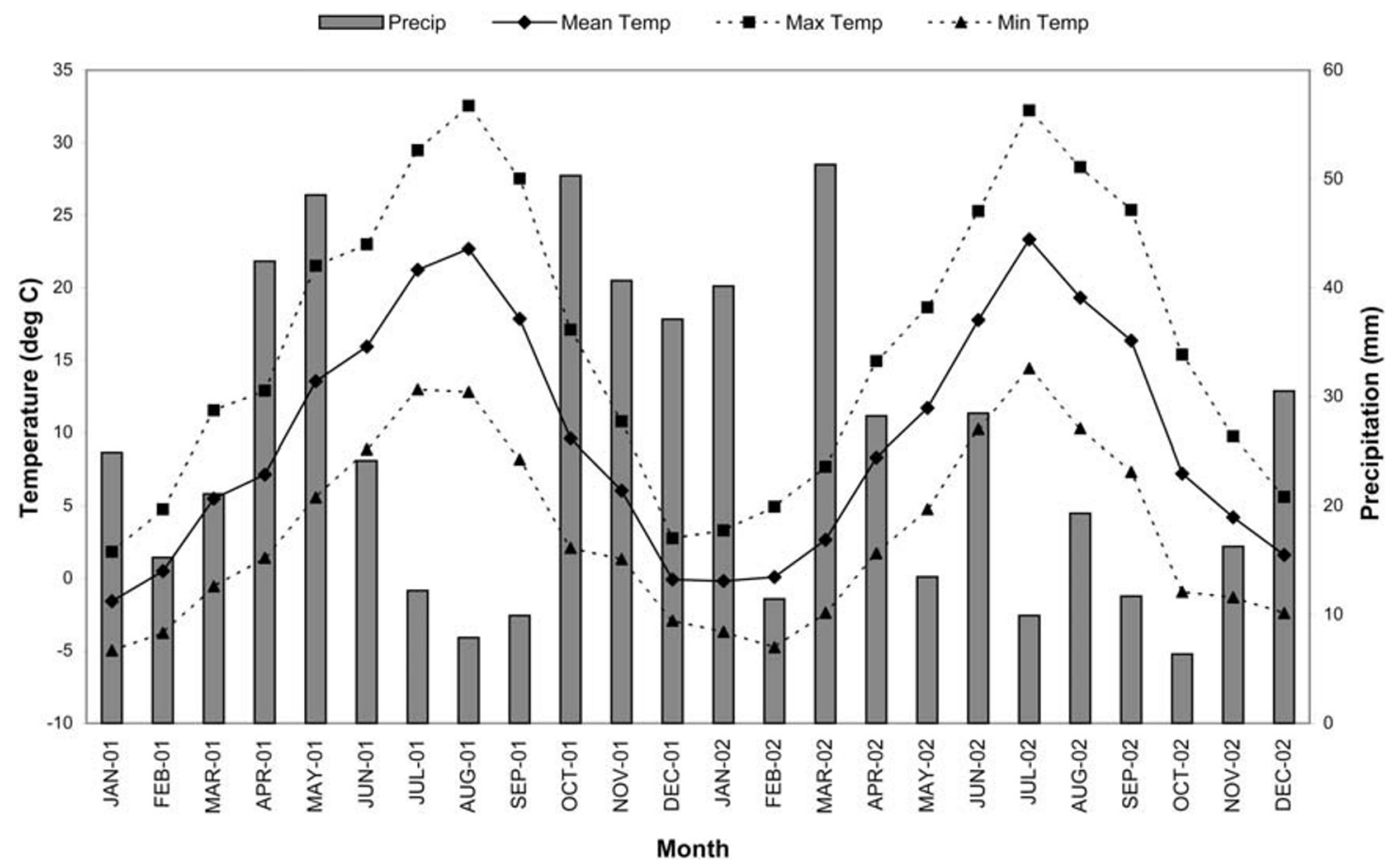

Figure 1. Climatic diagram for study areas in northeast Oregon, 2001 and 2002.

foil (Potentilla gracilis Dougl.) (Rice 1999; Mack 2000; Aitken and Parks 2004).

Sulfur cinquefoil has invaded a variety of habitats in North America and now occurs from British Columbia east to Newfoundland and Nova Scotia, south to Florida, and west to eastern Texas. In the western United States, the distribution of sulfur cinquefoil extends south to northern California and south in the Rocky Mountains to Wyoming. In the central and eastern United States, sulfur cinquefoil is considered to be primarily a minor agricultural weed (Werner and Soule 1976). In the western United States, sulfur cinquefoil frequently invades disturbed sites such as abandoned agricultural fields, meadows, pastures, and roadsides. However, relatively undisturbed bunchgrass communities, open-canopy ponderosa pine, drier Douglas-fir habitats, and seasonal wetland ecosystems are also susceptible to infestations by sulfur cinquefoil (Naylor et al. 2005). Over a period of 3 years, several sulfur cinquefoil colonies in Montana expanded to more than 400 contiguous hectares (Rice 1999). As yet, sulfur cinquefoil has not been reported to occur in the Great Basin, desert Southwest, southern Rockies, or the Rocky Mountain piedmont.

Limited information is available on the phenology, demography, and population ecology of sulfur cinquefoil in landscapes of the western United States. The species reproduces only by seed (achenes), has a single taproot, and may have several shallow, spreading branch roots but no rhizomes. Efforts to prevent the spread of sulfur cinquefoil and restore areas to native vegetation will benefit from an understanding of the mechanisms that allow sulfur cinquefoil to invade and persist. Our specific research objective was to characterize annual seed production and short-distance dispersal to better understand sulfur cinquefoil invasion ecology. Our broader objective is to identify species characteristics and environmental factors that might confer an advantage to the expansion of sulfur cinquefoil in northeast Oregon.

\section{METHODS}

\section{Study Sites}

The study area is located in the Blue Mountain province of northeast Oregon, a transitional area with both continental and maritime climatic influences (Franklin and Dyrness 1988). During fall, spring, and winter, this semiarid region is affected by maritime weather systems flowing through the Columbia River Gorge (Bryce and Omernik 1997). Average annual precipitation (1965-2003) for La Grande, Oregon, the largest city near the study sites, was $430 \mathrm{~mm}$ (Western Regional Climate Center 2004). Most precipitation occurs as snow from October through May, with periodic thunderstorms in the drier months of summer and early fall (Fig. 1). From 1965 to 2003, average daily air temperature ranged from $3^{\circ} \mathrm{C}$ to $16^{\circ} \mathrm{C}$, with an annual daily average of $9^{\circ} \mathrm{C}$.

Vegetation is dominated by a mixture of conifers, including Douglas-fir (Pseudotsuga menziesii [Mirbel] Franco), grand-fir (Abies grandis [Dougl.] Forbes), ponderosa pine (Pinus ponderosa Dougl.), Engelmann spruce (Picea engelmannii Parry), western larch (Larix occidentalis Nutt.), and lodgepole pine (Pinus contorta Dougl.), with the overstory composition depending largely on elevation, aspect, and soils (Franklin and Dyrness 1988). Understory vegetation is composed of a mixture of low-growing shrubs, mostly snowberry (Symphoricarpos [Duhamel] spp.) and wild rose (Rosa woodsii Lindl. and R. nutkana Presl.), and perennial native and nonnative forbs and graminoids (Franklin and Dyrness 1988). Soils in the 
Table 1. Physical site attributes, landownership, disturbance types, location, and description for study sites of sulfur cinquefoil populations in northeast Oregon.

\begin{tabular}{|c|c|c|c|c|c|c|c|c|}
\hline Site & Location & Ownership & $\begin{array}{l}\text { Elevation } \\
\qquad(\mathrm{m})\end{array}$ & Aspect & $\begin{array}{c}\text { Slope } \\
\left({ }^{\circ}\right)\end{array}$ & Disturbance & Description & $\begin{array}{c}\text { Sulfur } \\
\text { cinquefoil } \\
\text { density } \\
\text { (plants } / \mathrm{m}^{2} \text { ) }\end{array}$ \\
\hline Morgan Lake West & Lat $45^{\circ} 17^{\prime} 48.1^{\prime \prime} \mathrm{N}$, long $118^{\circ} 08^{\prime} 00.6^{\prime \prime} \mathrm{W}$ & City & 1285 & N & 6 & Mechanical & Forest opening near reservoir & 3.3 \\
\hline Morgan Lake East & Lat $45^{\circ} 17^{\prime} 48.1^{\prime \prime} \mathrm{N}$, long $118^{\circ} 08^{\prime} 00.6^{\prime \prime} \mathrm{W}$ & City & 1285 & N & 6 & Mechanical & Forest opening near reservoir & 2.9 \\
\hline Rice & Lat $45^{\circ} 17^{\prime} 13.8^{\prime \prime} \mathrm{N}$, long $118^{\circ} 06^{\prime} 18.0^{\prime \prime} \mathrm{W}$ & Private & 1225 & W & 15 & Mechanical & Forest opening near power line & 4.7 \\
\hline Red Bridge & Lat $45^{\circ} 17^{\prime} 39.5^{\prime \prime} \mathrm{N}$, long $118^{\circ} 19^{\prime} 55.7^{\prime \prime} \mathrm{W}$ & Private & 970 & NW & 3 & Mechanical & Riparian area—some shading & 3.6 \\
\hline Texaco & Lat $45^{\circ} 18^{\prime} 46.6^{\prime \prime} \mathrm{N}$, long $118^{\circ} 05^{\prime} 14.9^{\prime \prime} \mathrm{W}$ & Private & 854 & NE & 1 & Mechanical & $\begin{array}{l}\text { Vacant lot-city of La Grande, } \\
\text { Oregon }\end{array}$ & 2.7 \\
\hline Hamburger Hill & Lat $45^{\circ} 31^{\prime} 40.0^{\prime \prime} \mathrm{N}$, long $117^{\circ} 55^{\prime} 27.2^{\prime \prime} \mathrm{W}$ & Private & 860 & $\mathrm{E}$ & 6 & $\begin{array}{l}\text { Grazed by } \\
\text { livestock }\end{array}$ & Forest opening & 3.8 \\
\hline Foothill East & Lat $45^{\circ} 15^{\prime} 24.5^{\prime \prime} \mathrm{N}$, long $118^{\circ} 02^{\prime} 31.4^{\prime \prime} \mathrm{W}$ & State & 830 & E & 6 & Cultivated & Former agricultural field & 3.4 \\
\hline Foothill West & Lat $45^{\circ} 15^{\prime} 20.0^{\prime \prime} \mathrm{N}$, long $118^{\circ} 02^{\prime} 36.2^{\prime \prime} \mathrm{W}$ & State & 850 & $\mathrm{E}$ & 9 & $\begin{array}{l}\text { Grazed by } \\
\text { livestock }\end{array}$ & Forest opening & 1.3 \\
\hline
\end{tabular}

study area are variable, but most are derived from volcanic materials including volcanic debris and ash, andesite, basalts, rhyolites, and tuffs (Bryce and Omernik 1997).

The 8 study sites represented different disturbance histories and occurred over a range of elevations, aspects, and slopes (Table 1). The study sites were extensively infested with sulfur cinquefoil and ranged in size from approximately 1 to 5 ha. Each site was located within $500 \mathrm{~m}$ of a road, was influenced by human-related disturbances, and was open to grazing by native wildlife. The study sites were classified as "moderate integrity dry-forest rangeland" (Quigley et al. 1996), a common rangeland community type that extends across northeast Oregon. The sites were probably heavily grazed in the late 1800 s and early 1900s and have recovered over time as a result of decreased grazing pressure (Skovlin and Thomas 1995). Current land management disturbances were categorized as 1) mechanical soil disturbance, 2) cultivated, and 3) grazed by livestock (Table 1). Mechanical soil disturbance other than cultivation involved disturbance to the soil and vegetation by mechanized equipment associated with the building and maintenance of railroads, roads, developed recreation sites, and power lines. Maintenance activities in these areas required chronic vehicle traffic and included soil deposition and removal. Cultivation disturbance refers to agricultural tilling; the cultivated site (Foothill East) was plowed in the past and had been fallow for 7 years at the time of this study. Grazed sites have been continually grazed by wildlife, primarily elk and deer, and grazed by domestic livestock at different intensities for the past 70-100 years. Currently, these 2 sites receive moderate midseason grazing by cattle; during the years of this study (2001-2002), the sites maintained a "fair" rangeland condition.

\section{Seed Production}

To estimate seed (actually fruits, achenes) production, we collected sulfur cinquefoil plants in 2001 (24 July-24 August) and 2002 (23 July-30 July) just following peak flowering. At each site, entire plants (25-35 per site) representing the full range of plant size classes of reproductive plants (no rosettes) were collected at random, including all aboveground material and primary and secondary taproots. The single criterion for collection was that the plant had produced current-year flowers. Plants were carefully dug from the soil with trowels and shovel and were individually placed in plastic bags for transport. In the laboratory, the following attributes were recorded for each plant: number of stems, number of flowers per stem, and number of previous year's stems. The number of flowers per stem and the number of stems per plant were counted for 30-32 plants per site in 2001 and for 25 plants per site in 2002. In both years, we randomly selected 5 plants per site, then 5 flowers per plant, and counted the number of seeds per flower. To obtain an estimate of seed weight, we counted out batches ( $n=10$ seeds) of ripe seeds from 12-15 plants per site, weighed each batch, and divided by 10 .

\section{Seed Dispersal}

We measured dispersal of seeds from individual sulfur cinquefoil plants at all 8 sites ( 1 plant per site) from 25 July through 15 October 2001. Seed dispersal traps at Rice and Foothill West were repeatedly disturbed or destroyed by native ungulates, and results from these sites were not included in the analysis. At each site, random selection of a "source plant" was conducted using a combination of randomly generated numbers for distance and direction to locate potential candidate plants within the sulfur cinquefoil stand. We selected the first candidate plant that appeared to be of average height and stem number and that had not obviously released any seeds at the time of trap installation as the source plant for that site. We removed all sulfur cinquefoil plants within $5 \mathrm{~m}$ of the selected source plant. The following information was collected for each source plant: number of stems, number of flowers per stem, total number of flowers, and plant height. At each site, we also recorded elevation, aspect, and type of disturbance (Table 1).

Seed dispersal was measured by using sticky traps that are most commonly used for entomology research (Intercept Varroa Mite Traps ${ }^{\mathrm{TM}}$, IPM Technologies Inc, Portland, OR). These traps are constructed of durable sheets of poster board with a sticky layer of Tanglefoot ${ }^{\mathrm{TM}}$ on 1 side (Fig. 2). Traps were 


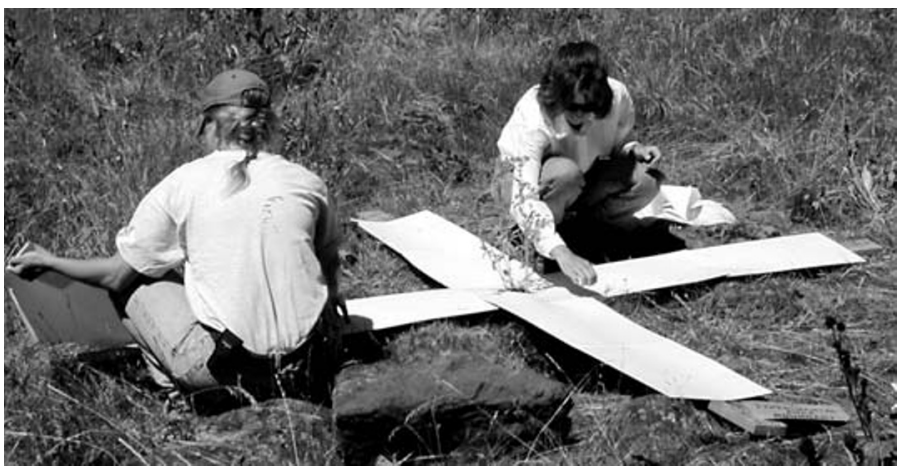

Figure 2. Method for trapping seeds, showing sticky traps $(1.0 \times 0.3$ m) radiating from central dispersal plant.

placed in 4 cardinal directions (north, south, east, and west) around each individual source plant. A $30 \times 30-\mathrm{cm}$ center trap was placed directly around the base of the selected dispersal plant and oriented north. Four wings, each composed of $230 \times$ $50-\mathrm{cm}$ sticky sheets attached on the end, were connected to the center trap. The length of each wing was about $100 \mathrm{~cm}$ from the edge of the center trap and $110 \mathrm{~cm}$ from the base of the dispersal plant itself (Fig. 2). The traps occupied approximately $32 \%$ of the circular area (radius $=110 \mathrm{~cm}$ ) surrounding each source plant. The traps were collected and replaced biweekly for 10 weeks. Following collection, traps were brought back to the lab and overlain with a $30 \times 50-\mathrm{cm}$ transparent piece of acetate marked in $2-\mathrm{cm}$ increments. For each direction, seeds captured on the sticky traps were counted in 2-cm intervals from the central source plant. Traps were removed from the field in mid-October, when plants were beginning to senesce and fall rains reduced the adhesive properties of the traps.

\section{Data Analysis}

The mean number of seeds produced per plant was calculated as the product of (mean number of seeds per flower) $\times$ (mean number of flowers per stem) $\times$ (mean number of stems per plant $)=$ estimated number of seeds produced per plant. Annual flower and seed production was estimated by averaging data from the 6 sulfur cinquefoil populations in 2001 and 2002. We assumed independence among the number of seeds per flower, number of flowers per stem, and number of stems per plant and calculated means and standard errors for site estimates of annual flower and seed production (Ramsey and Schafer 1997). For the 5 populations with data from both 2001 and 2002, between-year variation in number of seeds per flower, number of flowers per stem, and number of stems per plant was tested for each site by using unpaired Student's $t$ tests. The influence of site and year on seed, flower, and stem production was examined using nested analysis of variance (PROC Mixed), with plant nested within year $(2001,2002)$ as the basic sampling unit. Statistical analyses on seed production data were performed in SAS (SAS 2001).

To evaluate seed dispersal, the number of seeds captured was averaged for each sampling period $(n=24,6$ plants by 4 directions) and direction ( $n=6$ plants) and plotted against distance at $2-\mathrm{cm}$ intervals. The influence of source plant, direction, sampling period, and distance on the number of seeds captured was evaluated by using a series of generalized additive models, assuming both normal and Poisson distributions of the data (Hastie and Tibshirani 1990). In addition, the influence of interactions among source plant, direction, sampling period, and distance were tested assuming both normal and Poisson distributions. Statistical analyses on dispersal data were performed in S-PLUS (S-PLUS 2000).

\section{RESULTS}

\section{Seed Production}

The estimated number of sulfur cinquefoil seeds produced per plant (all sites combined) was about 6000 and was similar in 2001 and 2002 (Table 2). Between years, the average number of seeds per flower was similar at 4 out of 5 sites, the average number of flowers per stem was similar at 3 out of 5 sites, and the average number of stems per plant was similar at 4 out of 5 sites (Table 2).

Site conditions had a significant effect on the number of flowers per stem and the number of stems per plant (Table 3) but not the number of seeds per flower. For individual plants, the number of flowers per stem differed significantly, although the number of seeds per flower and the number of stems were similar. The highest seed production occurred at Foothill East, the formerly cultivated site (Table 2), where few other plant species were present, and sulfur cinquefoil formed a near monoculture. Average seed (achene) weight was $0.19 \mathrm{mg} \pm$ 0.04 standard deviation (SD; $n=2640$ from 5 different sites), and seeds ranged from 1.5 to $2.5 \mathrm{~mm}$ in length.

\section{Seed Dispersal}

The pattern of seed dispersal followed a decay function in which the number of captured seeds declined with distance from the source plant (Harper 1977; van der Valk 1992), and seeds were most abundant near the base of the source plants (Figs. 3A, 3B, and 4A). Although the dispersal curve is distinct, considerable variation is obvious, particularly for distances from 10 to $40 \mathrm{~cm}$, reflecting the influence of wind and sampling period. The model that explained the most variance in the pattern of captured seeds (i.e., resulted in the smallest residual deviance) was a generalized additive model that assumed a Poisson distribution of the data and included the following variables: source plant + sampling period + direction + lo(distance), where lo(distance) was a loess smoothed function of dispersal distance. The residual deviance was an order of magnitude smaller when assuming a Poisson distribution, thus resulting in a closer fit to the data. Adding interactions among the factors did not significantly improve the model. More than half the seeds were captured within $30 \mathrm{~cm}$ of the source plants, and approximately $83 \%$ of sulfur cinquefoil seeds were dispersed within $60 \mathrm{~cm}$ of the source plant (Fig. 3B).

Direction of the seed trap had a detectable influence on the number of captured seeds (Fig. 3A). Although wind speed and wind direction vary considerably throughout the study area, prevailing winds usually come from the south (Western Regional Climate Center 2004), as reflected in the seed dispersal patterns. Approximately 52\% of the captured seeds were dispersed in the combined north and west directions, and the fewest number of seeds, approximately $18 \%$, was dispersed in the southerly direction. The timing of seed maturation and 
Table 2. Mean number ( $\pm 1 \mathrm{SD}$ ) of seeds (achenes) per flower, flowers per stem, and stems per plant for sulfur cinquefoil in Union County, Oregon, 2001 and 2002. Within each site, different letters denote a significant difference between annual means (Student's $t$ tests; Pr $>|t|<0.01)$.

\begin{tabular}{|c|c|c|c|c|c|c|c|c|}
\hline \multirow[b]{3}{*}{ Site } & \multirow{2}{*}{\multicolumn{2}{|c|}{$\begin{array}{c}\text { No. seeds per flower }{ }^{1} \\
\text { Mean } \pm 1 \text { SD }\end{array}$}} & \multirow{2}{*}{\multicolumn{2}{|c|}{$\frac{\text { No. flowers per stem }{ }^{2}}{\text { Mean } \pm 1 \mathrm{SD}}$}} & \multirow{2}{*}{\multicolumn{2}{|c|}{$\frac{\text { No. stems per plant }^{2}}{\text { Mean } \pm 1 \text { SD }}$}} & \multirow{2}{*}{\multicolumn{2}{|c|}{ Estimated no. seeds per plant }} \\
\hline & & & & & & & & \\
\hline & 2001 & 2002 & 2001 & 2002 & 2001 & 2002 & 2001 & 2002 \\
\hline Morgan Lake West & $N A^{3}$ & $105 \pm 78$ & $22 \pm 13 \mathrm{a}$ & $16 \pm 9 b$ & $2.3 \pm 0.9 a$ & $2.1 \pm 0.8 \mathrm{a}$ & $N A$ & 3530 \\
\hline Morgan Lake East & $93 \pm 44 \mathrm{a}$ & $96 \pm 71 \mathrm{a}$ & NA & $13 \pm 7$ & NA & $2.1 \pm 1.0$ & NA & 2620 \\
\hline Rice & $108 \pm 28 a$ & $108 \pm 65 a$ & $18 \pm 8 a$ & $16 \pm 9 a$ & $2.8 \pm 1.0 \mathrm{a}$ & $2.7 \pm 1.7 \mathrm{a}$ & 5440 & 4665 \\
\hline Red Bridge & $142 \pm 31 \mathrm{a}$ & $84 \pm 76 b$ & $25 \pm 14 \mathrm{a}$ & $19 \pm 8 b$ & $2.5 \pm 1.9 \mathrm{a}$ & $3.1 \pm 1.7 \mathrm{a}$ & 8875 & 4950 \\
\hline Hamburger Hill & $99 \pm 23 a$ & $84 \pm 49 a$ & $14 \pm 6 \mathrm{a}$ & $18 \pm 11 \mathrm{a}$ & $2.0 \pm 0.9 \mathrm{a}$ & $2.4 \pm 1.8 \mathrm{a}$ & 2770 & 3630 \\
\hline Foothill East & $93 \pm 41 \mathrm{a}$ & $101 \pm 55 a$ & $34 \pm 20 \mathrm{a}$ & $30 \pm 17 a$ & $2.8 \pm 2.1 \mathrm{a}$ & $5.0 \pm 1.9 b$ & 8850 & 15150 \\
\hline Foothill West & $59 \pm 34$ & NA & $27 \pm 16 \mathrm{a}$ & NA & $2.5 \pm 1.2 \mathrm{a}$ & NA & 3980 & NA \\
\hline All Sites & $99 \pm 42 \mathrm{a}$ & $97 \pm 66 \mathrm{a}$ & $24 \pm 16 a$ & $20 \pm 13 a$ & $2.5 \pm 1.4 \mathrm{a}$ & $3.1 \pm 1.9 b$ & 5940 & 6015 \\
\hline
\end{tabular}

${ }^{1} n=25$ flowers; 5 flowers per plant, 5 plants per site.

${ }^{2} n=30-32$ plants per site in 2001; $n=25$ plants per site in 2002.

${ }^{3} \mathrm{NA}$ indicates data not available.

release is reflected in the number of seeds captured during each of the 5 sampling periods over the summer in 2001 (Fig. 4). Approximately one-third of the seeds were captured from late July through 16 August 2001, the first sampling period. Sulfur cinquefoil plants continued to release seeds through summer 2001, with the lowest number of seeds captured in the last 2 weeks of September (Fig. 4B). During the first 2 weeks of October, there appears to be an increase in the number of seeds captured, possibly due to windy and rainy conditions. By using the descriptive data collected for each source plant, we estimated the potential number of seeds that each plant would likely produce in the 2001 season and calculated the approximate proportion of seeds captured on the traps. Mean percentage of seeds captured was $17 \% \pm 0.04 \%$ SD (range $12 \%-22 \%, n=6)$. Stem and flower numbers of each source plant were within the range of the plants used to estimate seed production (Table 2).

\section{DISCUSSION}

\section{Seed Production}

Our estimates of seed production for sulfur cinquefoil in northeast Oregon are nearly 4-fold higher than previously reported for a single population of sulfur cinquefoil growing in southern Michigan (Werner and Soule 1976). In the Michigan study, the average number of seeds per flower was lower (mean $\pm \mathrm{SD}$, $61 \pm 28)$, the number of flowers per stem was comparable $(25 \pm 11)$, and the number of stems per plant was lower $(1.1 \pm$ 0.4 ). Because of more flowering stems and a higher number of seeds per flower, our estimates of seed production far exceeded theirs (6 000 vs. 1650 seeds per plant). We were unable to rigorously test the relationship between plant density and seed production; however, plant density did not appear to influence stem or flower numbers. At a northwestern Montana grassland site, sulfur cinquefoil plants produced an average of 123 seeds per flower (3-year average; P. Lesica, unpublished data, 2002), which is within the range of our estimate for both years. Higher seed production in populations of the western United States may be due to more favorable growing conditions or marked differences in regional genotypes (Barrett 2000). Because we calculated seed number on the basis of characteristics of plants collected in July and August, we likely underestimated the total annual seed production.

Many invasive plant species produce considerably more than 5000 to 6000 seeds per plant annually (Blossey and Notzold 1995). Sulfur cinquefoil plants, however, may flower and produce seeds in the first growing season, and we assume they continue to produce seeds throughout their lifetime. Plants have been reported to live from 20 to 30 years in Michigan (Rice 1991) and 10 years in Oregon (Perkins et al. 2006). Average age of sulfur cinquefoil plants in infested areas in northeast Oregon is 3 to 4 years $(3.5 \pm 0.10$ SE years; Perkins et al. 2006), so an “average" plant may produce over 19000 seeds in its life span. Sulfur cinquefoil seeds have high viability and germinability (Baskin and Baskin 1990); if even a fraction of the seeds germinate and establish successfully on

Table 3. Results of nested analysis of variance (ANOVA) for effects of site, year, and site $\times$ year interaction on the number of seeds per flower, the number of flowers per stem, and the number of stems per plant. For each ANOVA, plant (factor) was nested within year (2001, 2002).

\begin{tabular}{|c|c|c|c|}
\hline Source & df & $F$ & $\mathrm{Pr}>F$ \\
\hline \multicolumn{4}{|c|}{ Number of seeds per flower ${ }^{1}$} \\
\hline Site & 4,240 & 1.59 & 0.1771 \\
\hline Year & 1,240 & 3.46 & 0.0640 \\
\hline Site $\times$ year & 4,240 & 3.43 & 0.0094 \\
\hline \multicolumn{4}{|c|}{ Number of flowers per stem² } \\
\hline Site & 4,734 & 41.25 & $<0.0001$ \\
\hline Year & 1,734 & 7.56 & 0.0061 \\
\hline Site $\times$ year & 1,734 & 3.57 & 0.0068 \\
\hline \multicolumn{4}{|c|}{ Number of stems per plant ${ }^{3}$} \\
\hline Site & 3,214 & 9.48 & $<0.0001$ \\
\hline Year & 1,214 & 19.74 & $<0.0001$ \\
\hline Site $\times$ year & 3,214 & 3.17 & 0.0252 \\
\hline
\end{tabular}


A.

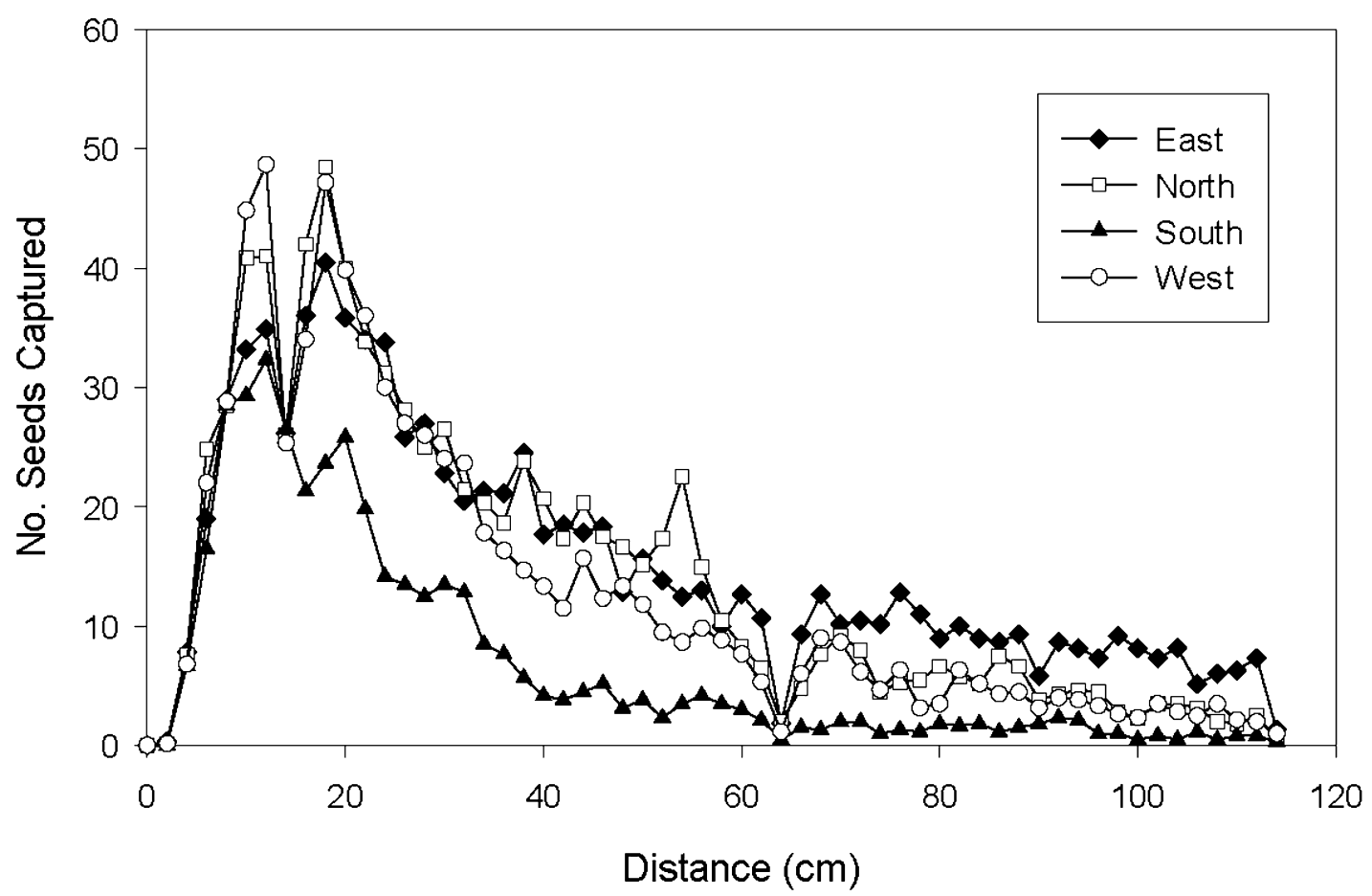

B.

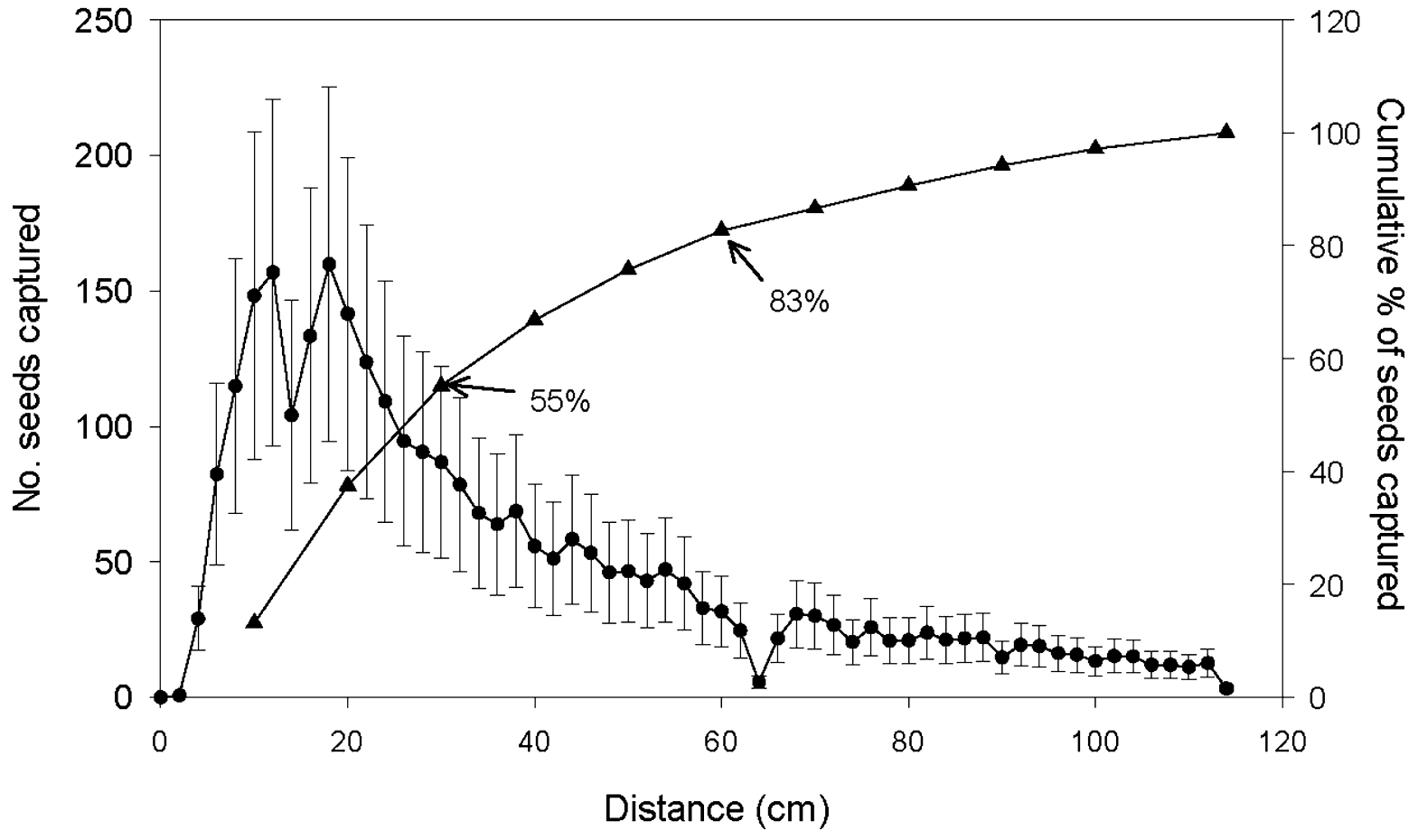

Figure 3. Mean number of sulfur cinquefoil seeds dispersed in the north, south, east, and west directions ( $n=6$ plants) from late July to midOctober 2001 in northeast Oregon (A); mean total number of seeds ( \pm 1 SD) captured and cumulative percentage of seeds captured against distance from source plant (B). 
A.

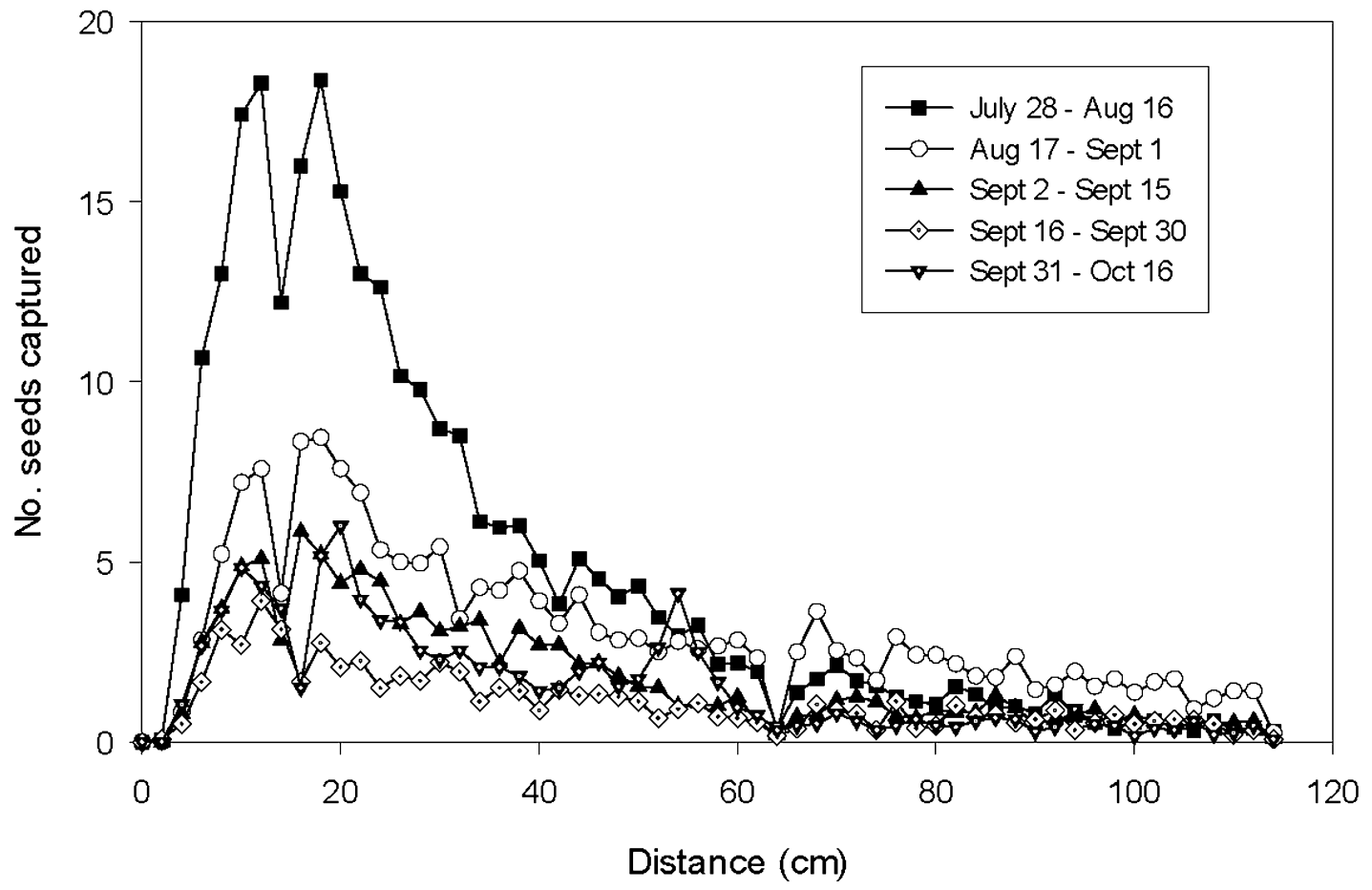

B.

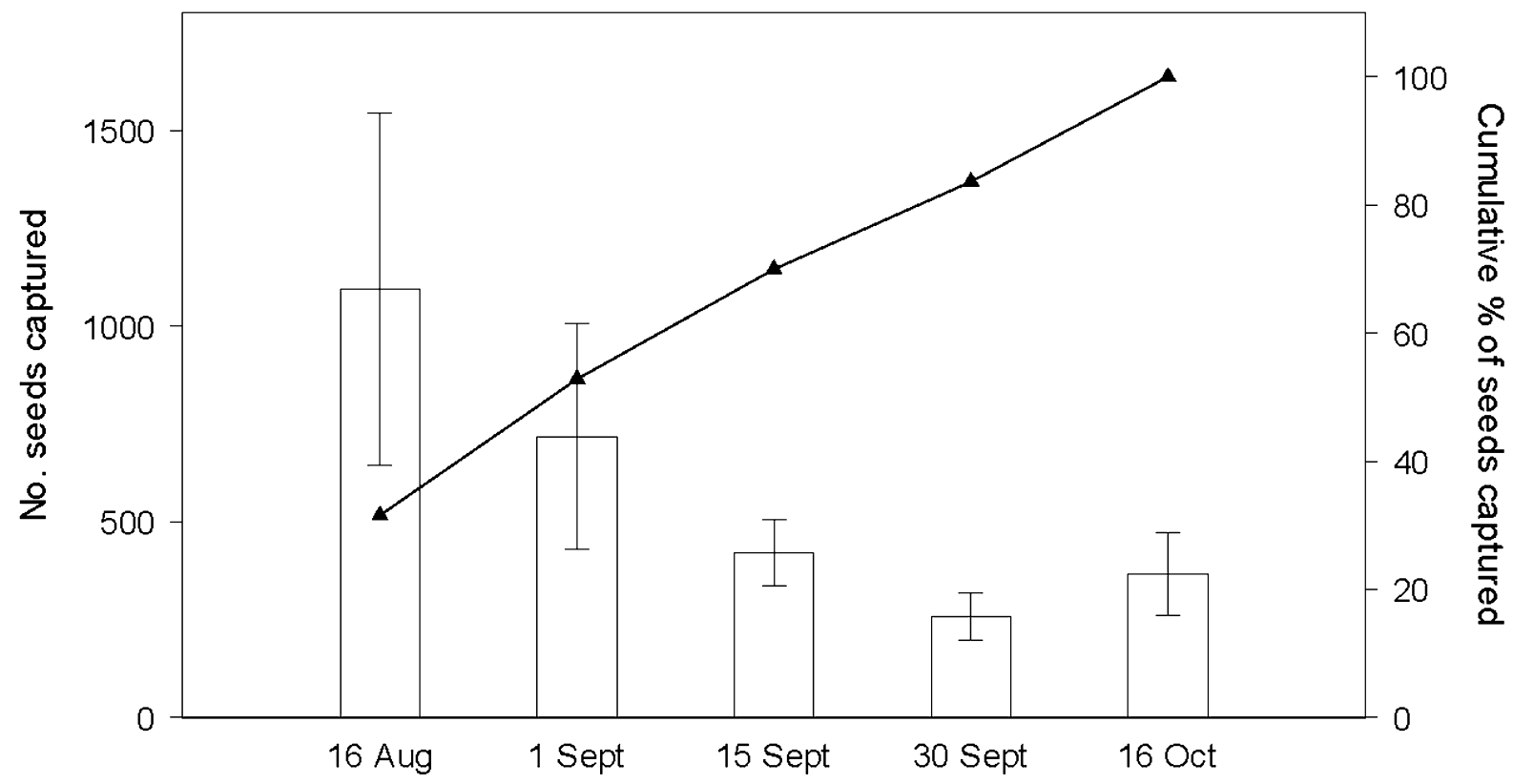

Sampling Period

Figure 4. Mean number of sulfur cinquefoil seeds ( $n=6$ sites) captured (A) and cumulative percentage of seeds captured (B) during each sampling period in northeast Oregon (2001). 
an annual basis, a local area may become dominated by sulfur cinquefoil within several years. In addition, Baskin and Baskin (1990) reported that percent germination of sulfur cinquefoil seeds did not decrease with more than 2 years of burial. Although Rice (1991) noted that sulfur cinquefoil seeds remain viable in the soil for up to 4 years, it is likely that viable seeds persist for considerably longer, and we speculate that sulfur cinquefoil may potentially dominate the seed bank in infested areas. Additional studies are needed to quantify sulfur cinquefoil seed longevity and propagule supply in the seed bank (Powell 1996).

Although little is known about the environmental requirements and competitive ability of sulfur cinquefoil, our results suggest that site conditions, including presence of native vegetation, influence reproductive capacity. In a northeast Montana grassland, the proportion of sulfur cinquefoil plants that produced seeds ranged from $3 \%$ to $86 \%$, was highly variable, and increased during years with higher precipitation. Further, plants produced more seeds per flower in the 2 wettest years, and the lowest number of seeds per flower occurred on the most xeric plot (P. Lesica, unpublished data, 2002). In northeast Oregon, average maximum temperature for the growing season (March-September) is $21.5^{\circ} \mathrm{C}$, average minimum temperature is $5.8^{\circ} \mathrm{C}$, and average annual precipitation is $250 \mathrm{~mm}$ (Western Regional Climate Center 2004). In our 2 study years, total precipitation from March through September was $16.5 \mathrm{~cm}$, considerably below the long-term average (Fig. 1). It is possible that seed production would exceed our estimates in wetter years.

\section{Seed Dispersal}

Use of seed traps allowed us to characterize the pattern of local seed rain for sulfur cinquefoil. While recognizing our relatively small sample size $(n=6)$, the standard decay function (dispersal curve, Fig. 3) occurred for each plant and likely represents the general pattern of short-distance dispersal for sulfur cinquefoil seeds. These results are consistent with previous observations that sulfur cinquefoil seeds are distributed by falling passively to the ground (Werner and Soule 1976). Sulfur cinquefoil seeds are relatively heavy and have no distinctive structures for wind or animal dispersal. The seed rain pattern (Fig. 3) suggests that once a population of sulfur cinquefoil is established in an area, it could potentially increase its range as an advancing front, expanding outward from source plants through short-distance dispersal (Grime 1979). Although sulfur cinquefoil seeds tend to fall near the source plant, wind direction does affect the fate of seeds. The influence of wind may explain why only $17 \%$ of the seeds were captured in approximately $32 \%$ of the circular area (radius $=110 \mathrm{~cm}$ ) surrounding the source plants. Wind direction is a local phenomenon and differs from site to site; however, it may be an important consideration in efforts to control expansion of sulfur cinquefoil populations.

Some seeds may have been released prior to installation of the seed traps; the selected source plants, however, appeared to be just setting seeds at the initiation of seed capture. Our observations of sulfur cinquefoil phenology in northeast Oregon over 3 years indicate that flowers begin to bloom in mid- to late June, seeds ripen and set in July, and the first seeds are released in late July (C. Parks, unpublished data, 20012003). Sulfur cinquefoil plants continue to produce and release seeds through September in northeast Oregon.

\section{IMPLICATIONS FOR MANAGEMENT, RESTORATION, AND FUTURE RESEARCH}

Our results suggest that seed production and short-distance dispersal may contribute substantially to the local expansion of sulfur cinquefoil populations. We speculate that when sulfur cinquefoil reaches a site, it persists and expands by producing many viable seeds, saturating the seed bank over time, and eventually outcompetes other species. Baker (1965) described an "ideal weed" as an adaptable perennial that is tolerant of a wide range of physical conditions, grows quickly, flowers early, is self-compatible, produces many seeds that disperse widely, reproduces vegetatively, and is a good competitor. Although sulfur cinquefoil does not reproduce vegetatively, it appears to have many of these traits and has become a problematic weed throughout much of the western United States (Endress and Parks 2004). Control of seed production and dispersal to prevent annual seed set would likely assist in managing expansion of sulfur cinquefoil populations. Restoration and management practices such as prescribed fire and herbicide application, which reduce the seed bank or promote seedling germination when environmental conditions are unfavorable for seedling growth, have potential as control methods if executed at the correct time and under specified conditions (Lesica and Martin 2003).

Whereas our results provide insight into how sulfur cinquefoil expands locally, new populations apparently establish via long-distance dispersal. Probable vectors include animals, people, and vehicles. Animals, particularly wild and domestic ungulates, may transport seeds in fur and hooves. Because many areas are grazed by livestock and native populations of deer and elk, it is important to address the role of these animals as vectors of seed dispersal and to design grazing management strategies that improve the ability of grazed native plants to compete with sulfur cinquefoil (Safford and Harrison 2001; Endress and Parks 2004). Dispersal by seed-eating birds may also occur. It is also likely that people hiking, horseback riding, and driving all-terrain vehicles inadvertently disperse numerous seeds. Because abundant seeds reside in the soil surface at infested sites, careful cleaning of soil from equipment and shoes before leaving the area may prevent new infestations. Each of our study sites was located near a road, and it is likely that the road network in the study area has served as a dispersal corridor and contributed to the increased spread of sulfur cinquefoil through both dispersal and increased disturbance (Formann and Alexander 1998; Gelbard and Belnap 2003; Riitters and Wickham 2003). Increased awareness of the identity of sulfur cinquefoil on both private and public lands may assist in early detection and may reduce further expansion (Aitken and Parks 2004).

The great majority of plant invasions occur in habitats that have been disturbed either naturally or by humans (Rejmánek 1989; Hobbs and Huenneke 1992; Hobbs 2000). In northeast Oregon, our sulfur cinquefoil study sites represented a range of 
disturbance from a severely disturbed cultivated field (Foothill East) to variously disturbed forest openings (Table 1). The formerly cultivated site supported a dense stand of sulfur cinquefoil and had the highest seed production in both 2001 and 2002 (Table 2). Although infested sites are visibly disturbed, scattered sulfur cinquefoil plants have also been observed in relatively undisturbed native forest (Endress and Parks 2004). Little is known about the ecological requirements, tolerances, and competitive ability of sulfur cinquefoil; however, it appears to be capable of establishing in a wide variety of habitats. For example, the importance of soil conditions on sulfur cinquefoil establishment and spread is unknown, though its wide distribution across North America suggests that it can tolerate a range of soil conditions, and it has been found to colonize areas with sandy, gravelly, rocky, and clay soils (Werner and Soule 1976; Rice 1991).

Studies are needed to determine ecological tolerances and to quantitatively demonstrate the competitive influence of sulfur cinquefoil. Observations suggest that sulfur cinquefoil displaces native grasses and forbs in grasslands and forest openings (Lesica and Martin 2003; Endress and Parks 2004). Because of its high tannin content, sulfur cinquefoil is unpalatable to most wildlife and livestock and tends to crowd out desirable forages (Rice 1999). In areas where sulfur cinquefoil grows with spotted knapweed, cattle prefer knapweed to cinquefoil (Rice 1999). It remains unclear which native species are directly at risk or which plant communities are most affected by the occurrence and expansion of sulfur cinquefoil. The co-occurrence of sulfur cinquefoil with similar native Potentilla species in many parts of the western United States provides an ideal situation to compare growth performance and examine competitive ability of congeners (Daehler 2003). Since the expansion of exotic plants continues to be a substantial management challenge in Oregon (Quigley et al. 1996), integrated strategies are needed to effectively control sulfur cinquefoil while promoting invasion-resistant native plant communities.

\section{ACKNOWLEDGMENTS}

We are grateful to resource managers at the USDA Forest Service, WallowaWhitman National Forest, Oregon, for sharing information on the local distribution of sulfur cinquefoil and to the Oregon Department of Fish and Wildlife, Ladd Marsh State Wildlife Area, and private landowners who allowed us to study sulfur cinquefoil on their properties. We thank Jimmy Lee and Marti Aitken for assistance in the field and Kacee Kennedy for assistance in the laboratory and field and with data entry and summary. We are grateful to Rudy King for statistical advice and to Rudy King and Laurie Porth for assistance with data analysis. Thanks to Rudy King, Jayne Hayes, Bryan Endress, Keith Owens, and 2 anonymous reviewers for providing insightful comments on previous drafts.

\section{LITERATURE CITED}

Aitken, M., and C. G. Parks. 2004. Guide to the common Potentilla species of the Blue Mountains ecoregion. Portland, OR: US Department of Agriculture, Forest Service, Pacific Northwest Research Station. General Technical Report PNWGTR-603. $50 \mathrm{p}$.

BAKER, H. G. 1965. Characteristics and modes of origin of weeds. In: H. G. Baker and G. L. Stebbins, [EDS.]. The genetics of colonizing species. New York: Academic Press. p 147-168.

BARRETT, S. 2000. Microevolutionary influences of global changes on plant invasions. In: H. A. Mooney and R. J. Hobbs [Eds.]. Invasive species in a changing world. Covelo, CA: Island Press. p 115-139.

BASKIN, J. M., AND C. C. BASKIN. 1990. Role of temperature and light in the germination ecology of buried seeds of Potentilla recta. Annals of Applied Biology 117:611-616.

Blossey, B., AND R. Notzold. 1995. Evolution of increased competitive ability in invasive non-indigenous plants: a hypothesis. Journal of Ecology 83: 887-889.

Britton, N. L., AND H. A. Brown. 1897. An illustrated flora of the northern USA and Canada. Volume 2. New York: Scribner. 655 p.

Bryce, S. A., And J. M. Omernik. 1997. Level IV ecoregions of the Blue Mountains ecoregion of Oregon, Washington, and Idaho. In: S. E. Clarke and S. A. Bryce [EDS.]. Hierarchical subdivisions of the Columbia plateau and Blue Mountains ecoregions, Oregon and Washington. Portland, OR: US Department of Agriculture, Forest Service, Pacific Northwest Research Station. General Technical Report PNW-GTR-395. p 24-55.

DaehleR, C. C. 2003. Performance comparisons of co-occurring native and alien invasive plants: implications for conservation and restoration. Annual Review of Ecology Evolution and Systematics 34:183-211.

Endress B. A., and C. G. Parks. 2004. Element stewardship abstract for Potentilla recta L., sulfur cinquefoil. The Nature Conservancy. Available at: http:// tncweeds.ucdavis.edu/esadocs/poterect.html. Accessed 16 November 2004.

Formann, R. T. T., and L. E. Alexander. 1998. Roads and their major ecological effects. Annual Review of Ecology and Systematics 29:207-232.

Franklin, J. F., and C. T. Dyrness. 1988. Natural vegetation of Oregon and Washington. Corvallis: Oregon State University Press. 452 p.

Gelbard, J. L., And J. Belnap. 2003. Roads as conduits for exotic plant invasions in a semiarid landscape. Conservation Biology 17:420-432.

GrIME, J. P. 1979. Plant strategies and vegetation processes. Chichester, UK: John Wiley and Sons. p 87-109.

HaRPER, J. L. 1977. The population biology of plants. New York: Academic Press. p 36-42.

Hastie, T. J., And R. J. TibshiRani. 1990. Generalized additive models. New York: Chapman and Hall. 335 p.

Hitchcock, C. L., and A. Cronquist. 1973. Flora of the Pacific Northwest. Seattle: University of Washington Press. 730 p.

HoвBs, R. J. 2000. Land-use changes and invasions. In: H. A. Mooney and R. J. Hobbs [EDS.]. Invasive species in a changing world. Covelo CA: Island Press. p 55-64.

HobBs, R. J., and L. F. Huenneke. 1992. Disturbance, diversity, and invasion: implications for conservation. Conservation Biology 6:324-337.

LesicA, P., AND B. Martin. 2003. Effects of prescribed fire and season of burn on recruitment of the invasive exotic plant, Potentilla recta, in a semiarid grassland. Restoration Ecology 11:516-523.

MaCK, R. N. 2000. Assessing the extent, status, and dynamism of plant invasions: current and emerging approaches. In: H. A. Mooney and R. J. Hobbs [EDS.]. Invasive species in a changing world. Covelo, CA: Island Press. p 141-168.

Naylor, B. J., B. A. Endress, and C. G. Parks. 2005. Multi-scale detection of sulfur cinquefoil using aerial photography. Rangeland Ecology \& Management 58: 447-451.

Perkins, D., C. G. Parks, K. A. Dwire, B. Endress, and K. Johnson. 2006. Age structure and age-related performance of sulfur cinquefoil. Weed Science 54:87-93.

PoweLL, G. 1996. Analysis of sulfur cinquefoil in British Columbia. Vancouver BC: Research Branch, B.C. Ministry of Forests, Forestry Division Services Branch. Paper 16. 35 p.

Quigley, T. M., R. W. Hayes, and R. T. Graham (teCh. eds.). 1996. An integrated scientific assessment for ecosystem management in the interior Columbia Basin and portions of the Klamath and Great Basins. Portland, OR: US Department of Agriculture, Forest Service, Pacific Northwest Research. General Technical Report PNW-GTR-382. 303 p.

Ramsey, F. L., And D. W. Schafer. 1997. The statistical sleuth: A course in methods of data analysis. Belmont, CA: Duxbury Press, Wadsworth Publishing. 742 p. ReJMÁnek, M. 1989. Invasibility of plant communities. In: J. A. Drake, H. A. 
Mooney, F. di Castri, R. H. Groves, F. J. Kruger, M. Rejmánek, and M. Williamson [EDS.]. Biological invasions: A global perspective. Chichester, UK: John Wiley and Sons. p 369-388.

RICE, P. M. 1991. Sulfur cinquefoil: a new threat to biological diversity. Western Wildlands 17:34-40.

RICE, P. M. 1999. Sulfur cinquefoil. In: R. L. Sheley and J. K. Petroff [EDS.]. Biology and management of noxious rangeland weeds. Corvallis: Oregon State University Press. p 382-387.

RIITTERS, K. H., AND J. D. WICKHAM. 2003. How far to the nearest road? Frontiers in Ecology and Environment 3:125-129.

Safford, H. D., and S. P. HaRrison. 2001. Grazing and substrate interact to affect native vs. exotic diversity in roadside grasslands. Ecological Applications 11: 1112-1122.

SAS [COMPUTER PROGRAm]. 2001. Version 8.2. SAS Institute, Inc, Cary, NC.

SKovLIN, J. M., AND J. W. Thomas. 1995. Interpreting long-term trends in Blue
Mountain ecosystems from repeat photography. Portland, OR: US Department of Agriculture, Pacific Northwest Research Station. General Technical Report PNW-GTR-315. $102 \mathrm{p}$.

S-PLUS [COMputer program]. 2000. Version 6.2 for Windows. Seattle, WA: Insightful Corporation.

van der Valk, A. G. 1992. Establishment, colonization and persistence. In: D. C. Glenn-Lewin, R. K. Peet, and T. T. Veblen [EDS.]. Plant succession: Theory and prediction. New York: Chapman and Hall. p 60-102.

Werner, P. A., and J. D. Soule. 1976. The biology of Canadian weeds. 18. Potentilla recta L., P. norvegica L., and $P$. argena L. Canadian Journal of Plant Science 56:591-603.

Western Regional Climate Center. 2004. National Climate Data Center Monthly Normals, 1965-2003, La Grande, Oregon. Reno, NV: Desert Research Institute. Available at: http://www.wrcc.dri.edu. Accessed 7 February 2004. 